\title{
Combination between Benzothiadiazole and Trichoderma Viride to Control Chocolate Spot Disease of Faba Bean and Their Effects on some Biochemical Characters
}

\author{
Mohamed A. Abd El-aal
}

\begin{abstract}
Faba bean is a food plant in many countries in the world. Botrytis fabae is a fungus that caused chocolate spot disease in faba bean . In this work, two concentrations of benzothiadiazole ( 0.3 and $0.5 \mathrm{mM}$ ) and suspensions of Trichoderma viride prepared in two concentrations $(1 \times$ $10^{7}$ and $2 \times 10^{7}$ spore $/ \mathrm{ml}$ ). The concentrations of benzothiadiazole and Trichoderma viride used alone and in combination to control chocolate spot disease in faba bean - Application of benzothiadiazole and Trichoderma viride reduced chocolate spot disease when used alone or in combination as foliar treatment . Total chlorophyll content and flavonoids content were increased when benzothiadiazole and Trichoderma viride used in treated plants compared to the infected control and to the plants treated with Tridex $80 \%$ wp .
\end{abstract}

Key Words: benzothiadiazole, Trichoderma viride, chocolate spot disease.

\section{INTRODUCTION}

Teosinte Faba bean is reach in energy and protein content and has a high nutritive value. Botrytis fabae is a fungus caused chocolate spot disease in faba bean . This desease appears on leaves, stems, flowers and pods which caused yield losses (Sahile et al., 2010 , Knany et al., 2009 and Elsayed et al,. 2016 ).

Benzothiadiazole (BTH) is an organic compound provide good protection to plant against many of plant pathogens ( Hafez 2010 and Nianlai et al., 2010).

Trichoderma spp. are fungi found in the soil and have antagonistic effect against many of phytopathogenic fungi ( Frac 2017 ). Trichoderma spp. used as biopesticides, biofertilizers and soil amendments in commercially marketed ( Frac et al., 2017 ) .

The objective of this study is to use benzothiadiazole and Trichoderma viride to control chocolate spot disease in faba bean each alone or in combination and compared their effect with the recomended fungicide ( Tridex $80 \% \mathrm{wp}$ ) .

\section{MATERIALS AND METHODS}

Benzothiadiazole [benzo-(1, 2, 3)-thiadiazole-7carbothioic acid S-methyl ester (BTH)] an organic compound used as aqueous solution in two concentrations, 0.3 and $0.5 \mathrm{mM}$. Obtainted from Elgomharia company .

$80 \% \mathrm{wp}$ : An organic wettable powder fungicide for the control and pre vention of various fungal diseases on crops .Active ingredient Mancozeb . Obtained from Ag chem company .

Trichoderma viride and Botrytis fabae growing on ( PDA ) medium in autoclaved plates . Trichoderma viride incubated at $25^{\circ} \mathrm{c}$ and Botrytis fabae incubated at $20{ }^{\circ} \mathrm{c}$. Hemocytometer slide was used to prepare spore suspensions which adjusted to $\left(2.5 \times 10^{7}\right.$ spore $\left./ \mathrm{ml}\right)$ for Botrytis fabae and $\left(1 \times 10^{7}\right.$ and $\left.2 \times 10^{7} \mathrm{spore} / \mathrm{ml}\right)$ for Trichoderma viride ( Jay et al., 2017 ) . Isolates were provide from department of plant pathology faculty of agriculture Alexandria university .

In each pot five seeds of faba bean were sown, under green house controled conditions. The experiment was contucted after 45 days from sowing (cv Giza 3). The growing seedlings were sprayed with T. viride and benzothiadiazole. Treatments are :

1.Plants sprayed with sterilized water only ( control ) .

2.Plants sprayed with Botrytis fabae ( untreated infected pathogen ).

3. Plants sprayed with Botrytis fabae + benzothiadiazole (BTH) at concentration $0.3 \mathrm{mM}$.

4. Plants sprayed with Botrytis fabae + benzothiadiazole $(\mathrm{BTH})$ at concentration $0.5 \mathrm{mM}$.

5. Plants sprayed with Botrytis fabae $+T$. viride at concentration $1 \times 10^{7}$ spore $/ \mathrm{ml}$.

6. Plants sprayed with Botrytis fabae $+T$. viride at concentration $2 \times 10^{7}$ spore $/ \mathrm{ml}$.

7. Plants sprayed with Botrytis fabae + benzothiadiazole / $T$. viride $\left(0.3 \mathrm{mM} \mathrm{/} 1 \times 10^{7}\right.$ spore/ml.

8. Plants sprayed with Botrytis fabae + benzothiadiazole / $T$. viride $\left(0.3 \mathrm{mM} \mathrm{/} 2 \times 10^{7}\right.$ spore/ml).

9. Plants sprayed with Botrytis fabae + benzothiadiazole / $T$. viride $\left(0.5 \mathrm{mM} \mathrm{/} 1 \times 10^{7}\right.$ spore/ml). 
10. Plants sprayed with Botrytis fabae+ benzothiadiazole / T. viride $\left(0.5 \mathrm{mM} / 2 \times 10^{7}\right.$ spore/ml).

After 50 days of sowing, the parameters were determind . Five pots were used as replicates for each treatment ( Harman et al., 2004 and Jay et al., 2017 ) .

Disease severity percentage was measured according to Hanounik (1986).

Total flavonoids was determind according to Hertog et al., (1992) and total chlorophyll content was determind according to method described by Procter (1981) and calculated using the formula reported by Arnon (1949) .Data were analysis according to (Gomez and Gomez 1984).

\section{RERSULTS AND DISCUSSION}

Using benzothiadiazole and Trichoderma viride alone or in combination reduced chocolate spot disease severity than untreated infected control . Increasing the concentrations of benzothiadiazole and Trichoderma viride increased the reduction in disease severity up to $91.68 \%$ agree with ( Frac et al., 2017 ) . Using benzothiadiazole alone was more effective than using
Trichoderma viride alone to control the disease. The highest reduction percentage was when using benzothiadiazole $(0.5 \mathrm{mM})$ and Trichoderma viride $(2 \times$ $10^{7}$ spore/ml) in combination up to the reduction percentage when using Tridex $80 \%$ wp , as shown in table 1 .

Increased in flavonoids content were obtained when using benzothiadiazole and Trichoderma viride alone or in combination than untreated infected plants ( Table 2 ). The flavonoids content significantly increased when using benzothiadiazole $(0.5 \mathrm{mM})$ and Trichoderma viride $\left(2 \times 10^{7}\right.$ spore/ml $)$ in combination close to Tridex $80 \%$ wp ( $1 \mathrm{~F}$ ) treatment agree with ( Jay et al., 2017 ) .

Increased in total chlorophyll content were obtained when using benzothiadiazole and Trichoderma viride alone or in combination than untreated infected plants agree with ( Philip et al., 2017 ) . The total chlorophyll content significantly increased when using benzothiadiazole $(0.5 \mathrm{mM})$ and Trichoderma viride $(2 \times$ $10^{7} \mathrm{spore} / \mathrm{ml}$ ) in combination up to Tridex $80 \% \mathrm{wp}(1 \mathrm{~F}$ ) treatment (Table 3).

Table 1 .Fungicidal activity of benzothiadiazole and $T$. viride alone or in combination on disease severity and reduction percentage of disease compared to Tridex $80 \%$ wp (mancozeb)

\begin{tabular}{cccc}
\hline Treatment & Concentration & \multicolumn{2}{c}{ B.fabae } \\
\cline { 3 - 4 } Benzothiadiazole(BTH) & & Disease Severity \% & Reduction \% \\
T.viride & $0.3 \mathrm{mM}$ & 21.11 & 56.06 \\
& $0.5 \mathrm{mM}$ & 11.75 & 75.55 \\
T.viride + BTH & $2 \times 10^{7} \mathrm{spore} / \mathrm{ml}$ & 33.12 & 31.06 \\
& $1 \times 10^{7} \mathrm{spore} / \mathrm{ml}$ & 27.14 & 43.51 \\
& $2 \times 10^{7} \mathrm{spore} / \mathrm{ml}+0.3 \mathrm{mM}$ & 15 & 68.78 \\
& $1 \times 10^{7} \mathrm{spore} / \mathrm{ml}+0.3 \mathrm{mM}$ & 11.10 & 76.90 \\
Tridex 80 \% wp & $2 \times 10^{7} \mathrm{spore} / \mathrm{ml}+0.5 \mathrm{mM}$ & 7.5 & 84.39 \\
(mancozeb) & $0.5 \mathrm{~F}$ & 4 & 91.68 \\
Untreated infected control & $1 \mathrm{~F}$ & 17.9 & 62.74 \\
L.S.D at 0.05 & $1.5 \mathrm{~F}$ & 3 & 93.76 \\
\hline
\end{tabular}

Table 2. Effect of using benzothiadiazole and Trichoderma viride alone or in combination on flavonoids content in faba bean leaves ( $\mathrm{mg} / \mathrm{gm}$ fresh weight ) compared to Tridex $80 \% \mathrm{wp}$ (mancozeb)

\begin{tabular}{ccc}
\hline Treatment & Concentration & Flavonoids content(mg/g fresh weight) \\
\cline { 3 - 3 } Benzothiadiazole(BTH) & & B.fabae \\
T.viride & $2 \times 10^{7} \mathrm{spore} / \mathrm{ml}$ & 1.48 \\
T.viride $+\mathrm{BTH}$ & $2 \times 10^{7}$ spore $/ \mathrm{ml}+0.5 \mathrm{mM}$ & 1.24 \\
Tridex $80 \% \mathrm{wp}$ & $1 \mathrm{~F}$ & 2.10 \\
(mancozeb) & & 2.30 \\
Infected control plants & - & 1.10 \\
Healthy control plants & - & 2.9 \\
L.S.D at 0.05 & & 0.06 \\
\hline
\end{tabular}


Table 3 .Effect of using benzothiadiazole and Trichoderma viride alone or in combination on total chlorophyll content in faba bean leaves ( $\mathrm{mg} / \mathrm{gm}$ fresh weight ) compared to Tridex $80 \% \mathrm{wp}$ (mancozeb)

Treatment
Benzothiadiazole(BTH)
T.viride
T.viride + BTH
$2 \times 10^{7} \mathrm{~s}$
Tridex 80\% wp (mancozeb)
Infected control Plants
Healthy Control Plants
L.S.D at 0.05
conclusion, results showed that using
In viride and benzothiadiazole in
Trichoderma spore/
combination was better than using each alone than
untreated infected plants respectively in reducing
chocolate spot disease, increasing total chlorophyll
content and increasing flavonoids content in faba bean
leaves . Using Trichoderma viride and benzothiadiazole
in combination more effective against this disease and
may be used as alternative to classical fungicides
Tridex $80 \%$ wp (mancozeb).

\section{REFERENCES}

Arnon, D.I. 1949 . Copper enzymes in isolated chloroplasts, polyphenolase in Beta vulgaise. Plant Pathol. 24:1-5.

Elsayed, A. A. A., A. A. I. Adss, M. Z. Dakroury . 2016. Effect of Salinity on Growth and Genetic Diversity of Broad Bean (Vicia faba L.) Cultivars . Alex. Sci. exch. j. 37: $467-479$.

FRAC. 2017. Fungicides sorted by mode of action. FRAC code list@2017. Fungicide Resistance Action Committeehttp://www.frac.info/docs/defau e/publi catio ns/frac-code-list/frac_code_list_2018final.pdf?sfvrs n=6144b 9a_2. Accessed 17 Apr 2018.

Gomez, K.A. and A.A.Gomez. 1984 . Statistical procedures for agricultural research. A. Lviley. Interscience Publication, New York. p 678 .

Hafez, Y.M. 2010 Control of Botrytis fabae by the resistance inducers benzothiadiazole (BTH) and hydrogen peroxide on white pepper fruits under post harvest storage. Acta Phytopathol et Entomol Hung. 45(1):13-29.

Hanounik, S.B. 1986. Screening techniques for disease resistance in faba bean. International Center for
B.fabae

Total chlorophyll

7.44

6.82

7.70

7.90

5.66

8.62

0.16

Agricultural Research in the Dry Areas Aleppo, Syria. p 59 .

Harman, G.E., C.R. Howell, A. Viterbo, I. Chet and M. Lorito. 2004.Trichoderma species-opportunistic, avirulent plant symbionts. Nature Rev. 2:43-56.

Hertog, M.G.L., P.C.H. Hollman and M.B. Katan. 1992. Content of potentially anticarcinogenic flavonoids of 28 vegetables and fruits commonly in the Netherlands. J. Agric Food Chem. 40:2379-2383 .

Jay, R. L., D. Carolyne, A. S. André, R. Marie-Hélène, S. Jean-Pierre, C. Vincent, M. Antoine and A. Jean-Noël. 2017 .Integrated management of damping-off diseases. A review Agron. Sustain. 37: 10-35.

Knany, R.E., R.H. Atia and A.S.M. El-Saady. 2009 . Response of Faba Bean to Foliar Spraying with Humic Substances and Micronutrients. Alex. Sci. exch. j.30: 453 -460 .

Nianlai, C., H. Qiao, C. Ping, N. XiaoYing and W. Rui. 2010. Effects of $\mathrm{BTH}, \mathrm{SA}$ and $\mathrm{SiO} 2$ treatment on disease resistance and leaf HRGP and lignin contents of melon seedlings. Sci Agric Sin. 43(3):535-541.

Philip. A.O.B. .2017. Biological control of plant diseases . Australasian Plant Pathol. 46:293-304 .

Procter, J.T.A. 1981. Stomatal conductance changes in leaves of Micntosh apple trees and after fruit removal. Can J Bot $.59: 50-53$

Sahile, S., C. Fininsa, P.K.Sakhuja and S. Ahmed. 2010 . Yield loss of faba bean (Vicia faba) due to chocolate spot (Botrytis fabae) in sole and mixed cropping systems in Ethiopia. Arch Phytopathol Plant Protect. 43(12):11441159 . 


\title{
الملخص العربي
}

\section{كفاءة خلط البنزوثياد(يزول و فطر التريكوديرما فردى ضد مرض البقعة الشيكولاتية (التبقع البنى) فى}

\section{الفول و تأثير ذلك على بعض الصفات البيوكيميائية}

\author{
محمد عادل عبد العال
}

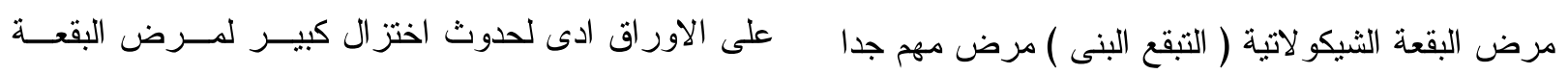

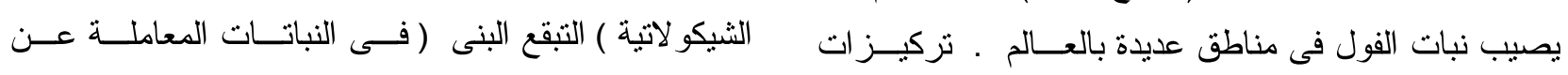

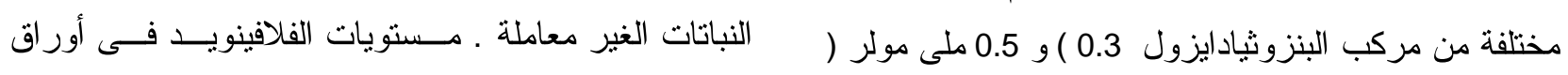

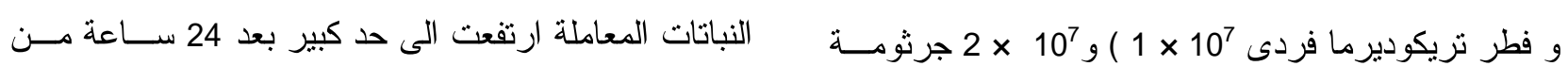

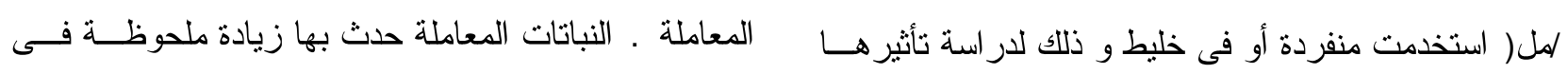

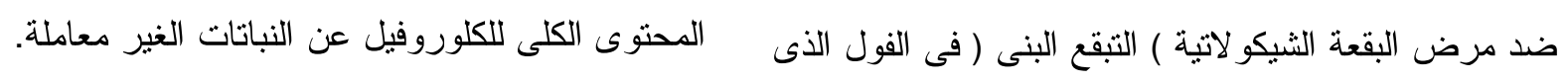

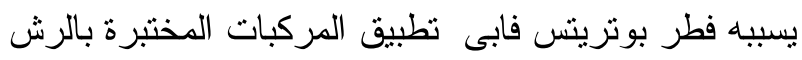

